Jurnal Inkofar * Volume 1 No. 2, Desember 2018 * ISSN: 2615-3645 (Print) / 2581-2920 (Online)

Tersedia secara online di: http://www.politeknikmeta.ac.id/meta/ojs/

\title{
RANCANG BANGUN SISTEM INFORMASI PENERIMAAN DAN PENGELUARAN KAS PADA PT. RHADOGEL GUMS INTERNASIONAL BEKASI
}

\author{
Widya Apriliah $^{1}$, Rahayu Ningsih ${ }^{2}$, Nurhidayah Ariyanti $^{3}$, Tri Haryati ${ }^{4}$ \\ 1,4 Program Pascasarjana Magister Ilmu Komputer/STMIK Nusa Mandiri Jakarta / \\ widyaapriliah64@gmail.com tri.trt@,bsi.ac.id \\ ${ }^{2}$ Sistem Informasi / Fakultas Teknologi Informasi / Universitas Bina Sarana Informatika / \\ rahayu.ryh@bsi.ac.id \\ ${ }^{3}$ Sistem Informasi Akuntansi / Fakultas Teknologi Informasi / Universitas Bina Sarana \\ Informatika / nurhidayahariyanti@gmail.com
}

\begin{abstract}
The development of the manufacturing world is now very large and is running fast, this is in accordance with BPS data throughout the 2017 Indonesian economy grew 5.07\% with the value of Gross Domestic Product (GDP) on the basis of current prices of Rp 13,588.8 trillion. Of these, the manufacturing sector contributed to GDP reaching Rp. 2,739.4 trillion. PT. Rhadogel Gums International is a company engaged in the trade of raw materials. Where this company still uses a system that has not been computerized in the process of recording and managing its financial data such as managing cash receipts and cash disbursements so that there are no small problems, for example in recording, processing transaction data and transaction reports requiring a long time and in data storage which is still not neatly stored. Then it takes a financial system that data processing is computerized, the author uses the waterfall method and visual basic applications in designing information systems for cash expenditure and income.
\end{abstract}

Keywords: System design, expenditure processing and cash inflow, waterfall

\begin{abstract}
ABSTRAK
Perkembangan dunia manufaktur sekarang sangat besar dan berjalan dengan cepat, hal ini sesuai dengan data BPS sepanjang 2017 ekonomi Indonesia tumbuh 5,07\% dengan nilai Produk Domestik Bruto (PDB) atas dasar harga berlaku sebesar Rp 13.588,8 triliun. Dari jumlah tersebut, sektor manufaktur menyumbang PDB mencapai Rp 2.739,4 triliun. PT. Rhadogel Gums Internasional adalah perusahaan yang bergerak di bidang perdagangan bahan baku. Dimana perusahaan ini masih menggunakan sistem yang belum terkomputerisasi dalam proses pencatatan dan pengelolaan data keuangannya seperti pengelolaan data penerimaan kas dan pengeluaran kas nya sehingga mengalami kendala yang tidak sedikit, misalnya dalam pencatatan, pengolahan data transaksi serta laporan transaksi membutuhkan waktu yang lama dan dalam penyimpanan data yang masih belum tersimpan rapi. Maka dibutuhkanlah sebuah sistem keuangan yang pengolahan datanya dilakukan secara komputerisasi, penulis menggunakan metode waterfall dan aplikasi visual basic dalam merancang sistem informasi pengeluaran dan pemasukan kas.
\end{abstract}

KataKunci : Perancangan Sistem, pengolahan pengeluaran dan pemasukan kas, waterfall.

\section{PENDAHULUAN}

Menteri Perindustrian Airlangga Hartarto di Jakarta, Ahad (repubika.co.id-11/2) memberikan beberapa pernyataan mengenai perkembangan perusahaan-perusahaan manufaktur. Manufaktur menjadi kunci penting guna memacu perekonomian nasional 
Jurnal Inkofar * Volume 1 No. 2, Desember 2018 * ISSN: 2615-3645 (Print) / 2581-2920 (Online)

Tersedia secara online di: http://www.politeknikmeta.ac.id/meta/ojs/

karena lebih produktif dan memberikan efek berantai yang luas.Menurut Airlangga, industri mampu meningkatkan nilai tambah bahan baku dalam negeri, menyerap banyak tenaga kerja, menghasilkan devisa dari ekspor, serta penyumbang terbesar dari pajak dan cukai. "Jangan sampai kita terus mengekspor sumber daya alam mentah kita tanpa pengolahan," ujarnya. Langkah pemerintah Indonesia yang sedang mendorong pertumbuhan ekonomi nasional dengan menggenjot sektor industri manufaktur juga dilakukan beberapa negara di kawasan Asia Tenggara, seperti Filipina dan Vietnam. "Bahkan, beberapa negara ASEAN sudah membuat roadmap Industry 4.0. Kita juga catching up di era ekonomi digital ini," katanya menambahkan. Melihat dari begitu besarnya peluang dan dukungan dari pemerintah terhadap perkembangan usaha manufaktur, maka tentu saja hal tersebut berkaitan dengan perusahaan-perusahaan yang menyediakan bahan aku mentah untuk perusahaan manufaktur tersebut. Sekretaris Jenderal Kementerian Perindustrian Haris Munandar menyatakan, tujuh sektor unggulan tersebut akan tetap menjadi fokus Kemenperin dalam meningkatkan pertumbuhan industri di Indonesia, "Penyumbang terbesar kita yang utama itu ada di industri makanan dan minuman yang menyumbang bagi PDB Industri pengolahan sekitar $33 \%$ dan masih menjadi andalan. Ada juga di farmasi, logam yang tahun ini akan ditambah kapasitasnya sejalan dengan smelter yang sudah berkembang. Itulah kenapa kita sangat optimistis pertumbuhan industri akan lebih baik," kata Haris, Rabu (finance.detik.com 21/3/2018). Data Badan Pusat Statistik (BPS) mencatat, sepanjang 2017 ekonomi Indonesia tumbuh 5,07\% dengan nilai Produk Domestik Bruto (PDB) atas dasar harga berlaku sebesar Rp 13.588,8 triliun. Dari jumlah tersebut, sektor manufaktur menyumbang PDB mencapai Rp 2.739,4 triliun

PT. Rhadogel Gums Internasional adalah perusahaan yang bergerak di bidang perdagangan bahan baku, dimana bahan baku utamanya adalah produk tepung jelly. Dimana perusahaan ini masih menggunakan sistem yang belum terkomputerisasi dalam proses pencatatan dan pengelolaan data keuangannya seperti pengelolaan data penerimaan kas dan pengeluaran kas nya sehingga mengalami kendala yang tidak sedikit, misalnya dalam pencatatan, pengolahan data transaksi serta laporan transaksi membutuhkan waktu yang lama dan dalam penyimpanan data yang masih belum tersimpan rapi. Maka dibutuhkanlah sebuah sistem keuangan yang pengolahan datanya dilakukan secara komputerisasi, penulis menggunakan metode waterfall dan aplikasi visual basic dalam merancang sistem informasi pengeluaran dan pemasukan kas.

\section{STUDI PUSTAKA}

\subsection{Sistem}

Menurut Sutabri (2012 : 10) "Sistem dapat diartikan sebagai suatu kumpulan atau himpunan dari sistem, komponen, atau variabel yang terorganisir, saling berinteraksi, saling tergantung satu sama lain dan terpadu".

\subsection{Informasi}

Menurut Puspitawati dan Anggadini (2011:13) "Informasi adalah data yang diolah menjadi bentuk yang lebih berguna dan lebih berarti bagi yang menerimanya".

\subsection{Sistem Informasi}

Menurut Sutabri (2012:38) "Sistem informasi adalah suatu sistem didalam suatu organisasi yang mempertemukan kebutuhan pengolahan transaksi harian yang mendukung fungsi operasi organisasi yang bersifat manajerial dengan kegiatan startegi dari suatu organisasi untuk dapat menyediakan laporan-laporan yang diperlukan oleh pihak luar tertentu”.

Sistem informasi akademik menurut Gamaliel (2017:25) adalah singkronisasi antara laporan akademik perguruan tinggi dengan aplikasi Feeder sehingga perlu di buat sebuah rancang bangun sistem informasi akademik yang selaras dengan aplikasi Feeder.

Berdasarkan berkiatan dengan sistem informasi diatas dapat diberikan kesimpulan bahwa informasi dihasilkan dari sebuah data yang diproses pada sebuah sistem menjadi sebuah 
Jurnal Inkofar * Volume 1 No. 2, Desember 2018 * ISSN: 2615-3645 (Print) / 2581-2920 (Online)

Tersedia secara online di: http://www.politeknikmeta.ac.id/meta/ojs/

laporan yang diperlukan dalam mendukung fungsi operasi organisasi untuk pengambilan keputusan.

2.4 Sistem Akuntansi Penerimaan Kas

Menurut Hery (2012:185) "Sebagian besar penerimaan kas tentu saja berasal dari kegiatan normal bisnisnya, yaitu melalui penjualan tunai (baik untuk perusahaan dagang maupun jasa). Ataupun sebagai hasil penagihan piutang usaha dari pelanggan (dalam hal penjualan kredit)".

2.5 Sistem Akuntansi Pengeluaran Kas

Menurut Baridwan (2010:85) "Pengeluaran kas dalam suatu perusahaan itu adalah untuk membayar bermacam-macam transaksi. Apabila pengawasannya tidak dijalankan dengan ketat, seringkali jumlah pengeluaran diperbesar dan selisihnya digelapkan".

2.6 Basis Data

Menurut Kristanto dalam Muharam, dkk (2018:112) Basis data (Database) adalah kumpulan dari data, yang dapat digambarkan sebagai aktifitas dari satu atau lebih organisasi yang berelasi. Secara umum menurut muharam dkk (2018:112) sebuah sistem basis data atau yang disebut dengan DBMS (Data Base Management Systems) adalah sekumpulan tabel data yang saling berhubungan yang memungkinkan.

\subsection{Entity Relationship Diagram (ERD)}

Menurut Sukamto dan Salahuddin (2013:50), "ERD atau Entity Relationship Diagram merupakan sebuah diagram yang digunakan untuk merancang hubungan antar tabel-tabel dalam basis data".

Menurut Kuryanti (2016:86) ERD juga digunakan untuk "menggambarkan hubungan antara satu entitas yang memiliki sejumlah atribut dengan entitas yang lain dalam suatu perancang sistem untuk memodelkan data yang nantinya akan dikembangkan menjadi basis data (database)".

2.8 Logical Record Structure (LRS)

Menurut Nugraha dan Octasia (2016:300) "LRS (Logical Record Structure) merupakan representasi dari struktur record-record pada tabel-tabel yang terbentuk dari hasil relasi antar himpunan entitas pada diagram E-R".

2.9 Data Flow Diagram (DFD)

Menurut kendall dan Kendall (2011:217) "Data flow diagrams are structured analysis dan design tools that allow the analyst to comprehend the system and subsystem visually as a set of interrelated data flows".

Berdasarkan kutipan diatas, penulis memberikan kesimpulan bahwa diagram alir data yaitu alat yang didesain secara terstruktur yang memungkinkan seorang analis sistem dapat dengan mudah memahami sistem dan subsistem dalam sebuah perusahaan dan kemudian dapat menggambarkannya dalam bentuk visual diagram menjadi satu set arus data yang saling terkait.

\section{METODE PENELITIAN}

3.1 Metode Pengembangan Perangkat Lunak

Dalam pengembangan sistem informasi ini peneliti menggunakan metode SDLC (Software Development Life Cycle), metode SDLC ini menurut sukamto (2013:26) adalah proses mengembangkan atau mengubah suatu system perangkat lunak menggunakan model-model dan metodologi untuk mengembangkan system system-sistem perangkat lunak sebelumnya (berdasarkan best practise atau cara-cara yang sudah teruji baik). Model dalam metode SDLC yang digunakan dalam penelitian ini adalah dengan menggunakan model waterfall. Model waterfall dalam jurnal yang ditulis oleh Sholikhah Imroatus, Mahmud Sairan dan Nurfia Oktaviani Syamsiah adalah model klasik yang bersifat sistematis, berurutan dalam membangun software. Adapun tahapan yang ada pada model waterfall secara global adalah : 
Jurnal Inkofar * Volume 1 No. 2, Desember 2018 * ISSN: 2615-3645 (Print) / 2581-2920 (Online)

Tersedia secara online di: http://www.politeknikmeta.ac.id/meta/ojs/

1. Analisa Kebutuhan Sistem

Tahapan dalam proses ini merupakan analisa kebutuhan system yang terdiri dari menumenu yang diperlukan dalam pengolahan data penerimaan kas dan pengeluaran kas, mencakup menu-menu antara lain: Menu Master yang memiliki submenu pengguna, submenu barang, submenu konsumen, submenu pemasok dan submenu perkiraan. Menu transaksi yang memiliki submenu rekap penjualan, submenu pembayaran, submenu kas masuk dan kas keluar, submenu permintaan persediaan barang, submenu purchase order, submenu struk acc. Menu laporan transaksi yang memiliki submenu laporan rekap penjualan, submenu laporan pembayaran, laporan pemasukan kas, submenu laporan persediaan barang, submenu laporan purchase order, submenu laporan struk acc, submenu laporan pengeluaran kas, submenu laporan jurnal, submenu laporan pengeluaran dan penerimaan kas. Menu exit terdiri dari submenu backup dan submenu keluar.

2. Desain

Tahapan dalam proses desain pada penelitian ini meliputi rancangan sistem dengan menggunakan diagram alir data dan rancangan database menggunakan entity relationship diagram dan logical record structure.

3. Pengkodean

Setelah melalui tahap desain, maka desain harus ditranslasikan kedalam sebuah aplikasi program. Program yang dibuat dalam penelitian ini termasuk kedalam pemrograman terstruktur dengan Bahasa pemrograman yang digunakan adalah Visual Basic 6.0.

4. Pengujian

Tahapan dalam proses pengujian pada penelitian ini dilakukan dengan menggunakan blackbox testing.

\subsection{Metode Pengumpulan Data}

1. Observasi

Suatu pengamatan secara langsung terhadap segala permasalahan yang akan menjadi objek penelitian atau melakukan peraktek kerja lapangan ataupun riset di PT. Rhadogel Gums Internasional dan dicatat oleh penulis sehingga dapat mengetahui kesalahan dan proses pada suatu kegiatan.

\section{Wawancara}

Dalam hal ini penulis melakukan wawancara atau menanyakan secara langsung kepada bagian keuangan mengenai arus penerimaan dan pengeluaran kas.

\section{Kajian Literature}

Metode Kepustakaan adalah mencari data dan fakta dengan mengkaji sumber-sumber pustaka yang berhubungan dengan objek penelitian. Untuk menambah bahan acuan, penulis juga melakukan pengumpulan data secara teoritis yang berguna dalam penyusunan sistem penerimaan dan pengeluaran kas dengan jalan mempelajari bahan-bahan yang ada di perpustakaan berupa buku dan referensi lain yang berhubungan dengan masalah yang sedang dihadapi.

\section{Hasil dan pembahasan}

\subsection{Analisa Sistem Berjalan}

Prosedur sistem penerimaan dan pengeluaran kas pada PT. Rhadogel Gums Internasional sebagai berikut:

a. Proses Penerimaan Kas

Customer melakukan pembayaran atas transaksi penjualan sebelumnya dengan memberikan bukti bayar serta invoice copy sebagai bukti penerimaan pembayaran kepada administrasi. Lalu administrasi mengambil invoice asli untuk ditukar dengan invoice copy sebagai bukti pelunasan. Kemudian invoice copy diarsipkan dan 
Jurnal Inkofar * Volume 1 No. 2, Desember 2018 * ISSN: 2615-3645 (Print) / 2581-2920 (Online) Tersedia secara online di: http://www.politeknikmeta.ac.id/meta/ojs/

administrasi memproses data penjualan tersebut dengan cara merekap dan diarsipkan ke dalam rekap penjualan.

b. Proses Pencatatan Penerimaan Kas

Kemudian dari hasil rekap penjualan lalu administrasi mencatat dan diarsipkan ke dalam bukti pemasukan bank/kas.

c. Proses Pengeluaran Kas

Pada proses ini inventory memberikan informasi persediaan lalu administrasi membuat purchase order atas pemesanan barang dagang tersebut dan menyerahkan kepada direktur untuk di acc setelah di acc kemudian purchaseorder acc diberikan kepada supplier serta purchase order acc copy diarsipkan dan bagian inventory serta bagian produksi menyerahkan struk transaksi pembelian kepada administrasi. Kemudian pengajuan struk akan di acc oleh administrasi, setelah di acc lalu administrasi memberikan data bayar kepada inventory dan produksi serta struk acc akan diarsipkan ke dalam arsip struk acc.

d. Proses Pencatatan Pengeluaran Kas

Dari arsip struk acc dan purchase order acc copy administrasi akan mencatat dan mengarsipkannya ke dalam bukti pengeluaran bank/kas.

e. Proses Pembuatan Laporan Penerimaan dan Pengeluaran Kas dari arsip bukti pemasukan bank/kas dan bukti pengeluaran bank/kas akan dibuatkan laporan penerimaan dan pengeluaran kas bulanan yang akan diserahkan kepada direktur serta mengarsipkan laporan copy.

\subsection{Data Flow Diagram (DFD) Sistem Berjalan}

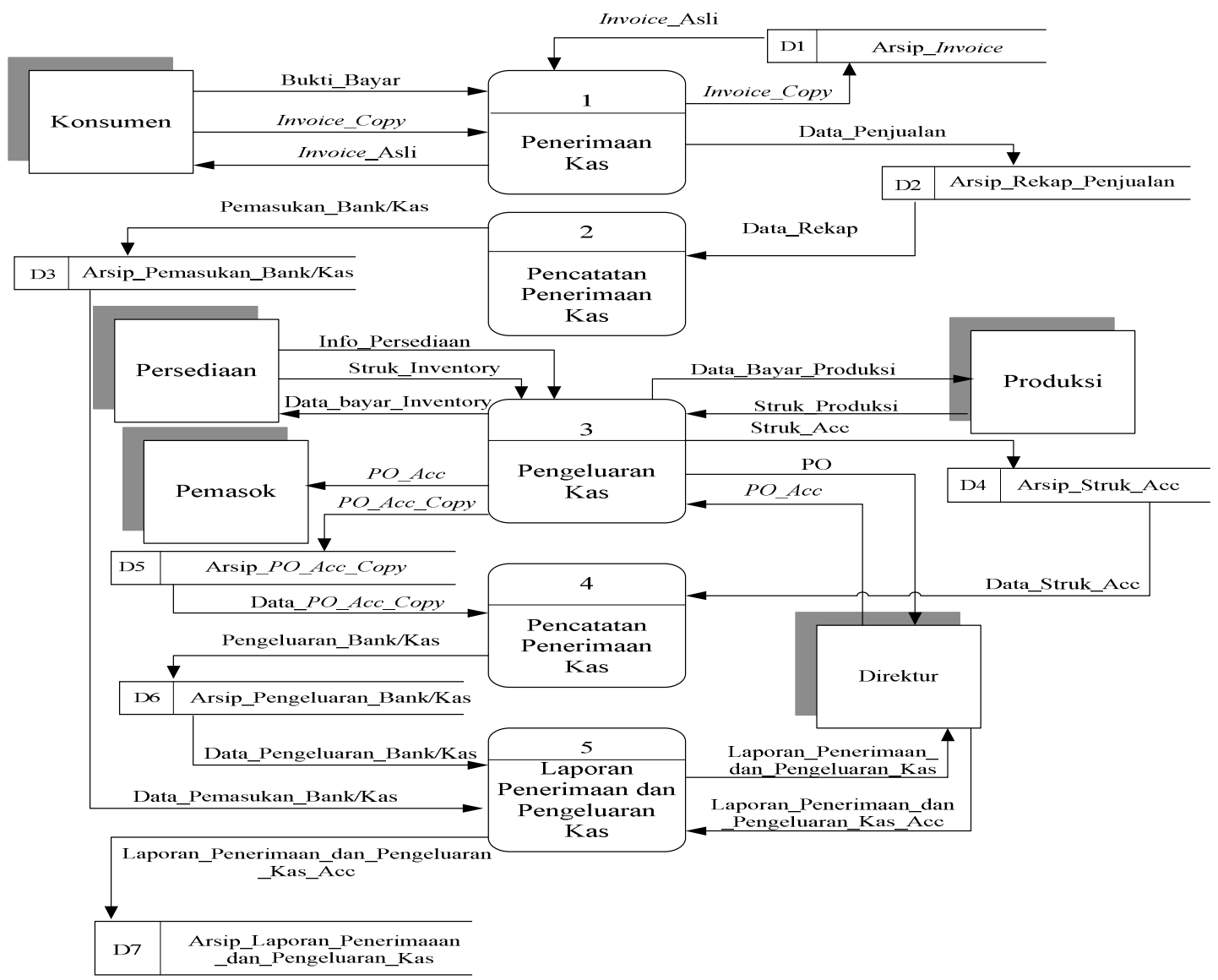

Gambar 1. Diagram Sistem Akuntansi Berjalan 
Jurnal Inkofar * Volume 1 No. 2, Desember 2018 * ISSN: 2615-3645 (Print) / 2581-2920 (Online)

Tersedia secara online di: http://www.politeknikmeta.ac.id/meta/ojs/

\subsection{Analisa Sistem Usulan}

Berikut ini penulis mencoba menerangkan bagaimana proses yang yang perlu diketahui agar dapat dimengerti, tentang data-data penerimaan dan pengeluaran kas perusahaan secara detail dari proses penerimaan dan pengeluaran kas sampai proseslaporan penerimaan dan pengeluaran kas.

1. Proses Penerimaan Kas

Customer melakukan pembayaran atas transaksi penjualan sebelumnya dengan memberikan data bayar serta invoice copy sebagai bukti penerimaan kepada administrasi. Lalu berdasarkan invoice copy tersebut administrasi menginputkan data ke dalam file rekap penjualan dan file pembayaran. Kemudian mengambil invoice asli untuk ditukar dengan invoice copy serta mencetak bukti bayar dan menyerahkan kepada customer sebagai bukti pelunasan.

2. Proses Pencatatan Penerimaan Kas

Dari file pembayaran lalu administrasi menginputkan data pembayaran ke dalam file pemasukan kas sebagai bukti penerimaan kas. Dan akan dicetak bukti pemasukan kas jika diperlukan.

3. Proses pengeluaran Kas

Pada proses ini bagian persediaan memberikan informasi permintaan persediaan barang kepada administrasi. Lalu administrasi menginputkan data informasi tersebut ke dalam file PPB lalu dicetak dan diserahkan kepada persediaan untuk di acc. Berdasarkan PPB acc administrasi membuatkan purchase order yang disimpan ke dalam file purchase order lalu untuk data supplier dan data barangnya administrasi mengambilnya dari file pemasok dan file barang kemudian dicetak dan diberikan kepada direktur untuk di acc dan PPB acc diarsipkan. Setelah di acc, purchase order tersebut diberikan kepada pemasok yang namanya sudah tertera di dokumen tersebut lalu purchase ordercopy di arsipkan. Dari bagian produksi dan persediaan menyerahkan struk transaksi pembelian kepada administrasi. Kemudian pengajuan struk akan di acc oleh administrasi, setelah di acc lalu administrasi menginput data struk acc tersebut ke dalam file struk acc lalu mencetak bukti tanda terima dan diserahkan kepada produksi dan persediaan untuk di acc. Kemudian bukti tanda terima acc dan struk acc akan diarsipkan ke dalam arsip struk acc.

4. Proses Pencatan Pengeluaran Kas

Dari file struk acc dan file PO administrasi akan mencatat dan menyimpannya ke dalam file pengeluaran kas. Dan akan dicetak bukti pengeluarkan kas jika diperlukan.

5. Proses Penjurnalan Penerimaan dan Pengeluaran Kas

Dari file pemasukan kas dan file pengeluaran kas, administrasi akan menjurnal seluruh transaksi ke dalam file jurnal.

6. Proses Pembuatan Laporan Penerimaan dan Pengeluaran Kas

Administrasi akan membuat laporan penerimaan dan pengeluaran kas berdasarkan data jurnal yang akan diserahkan kepada direktur sebagai laporan penerimaan dan pengeluaran kas bulanan. Setelah di acc oleh direktur laporan tersebut diarsipkan. 
Jurnal Inkofar * Volume 1 No. 2, Desember 2018 * ISSN: 2615-3645 (Print) / 2581-2920 (Online) Tersedia secara online di: http://www.politeknikmeta.ac.id/meta/ojs/

\subsection{Data Flow Diagram (DFD) Sistem Usulan}

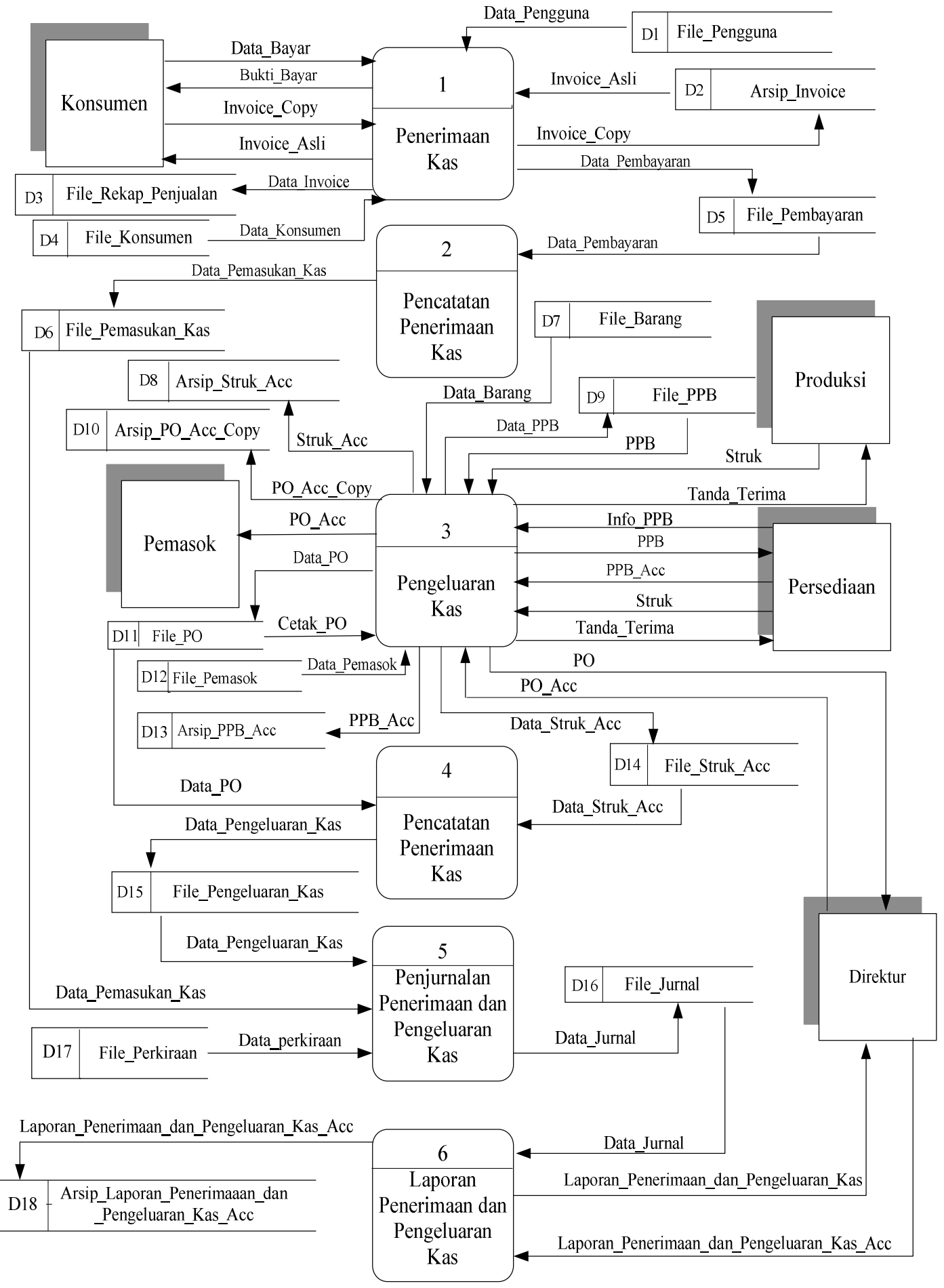

Gambar 2. Diagram Sistem Akuntansi Usulan 
Jurnal Inkofar * Volume 1 No. 2, Desember 2018 * ISSN: 2615-3645 (Print) / 2581-2920 (Online) Tersedia secara online di: http://www.politeknikmeta.ac.id/meta/ojs/

\subsection{Entity Relational Diagram (ERD)}

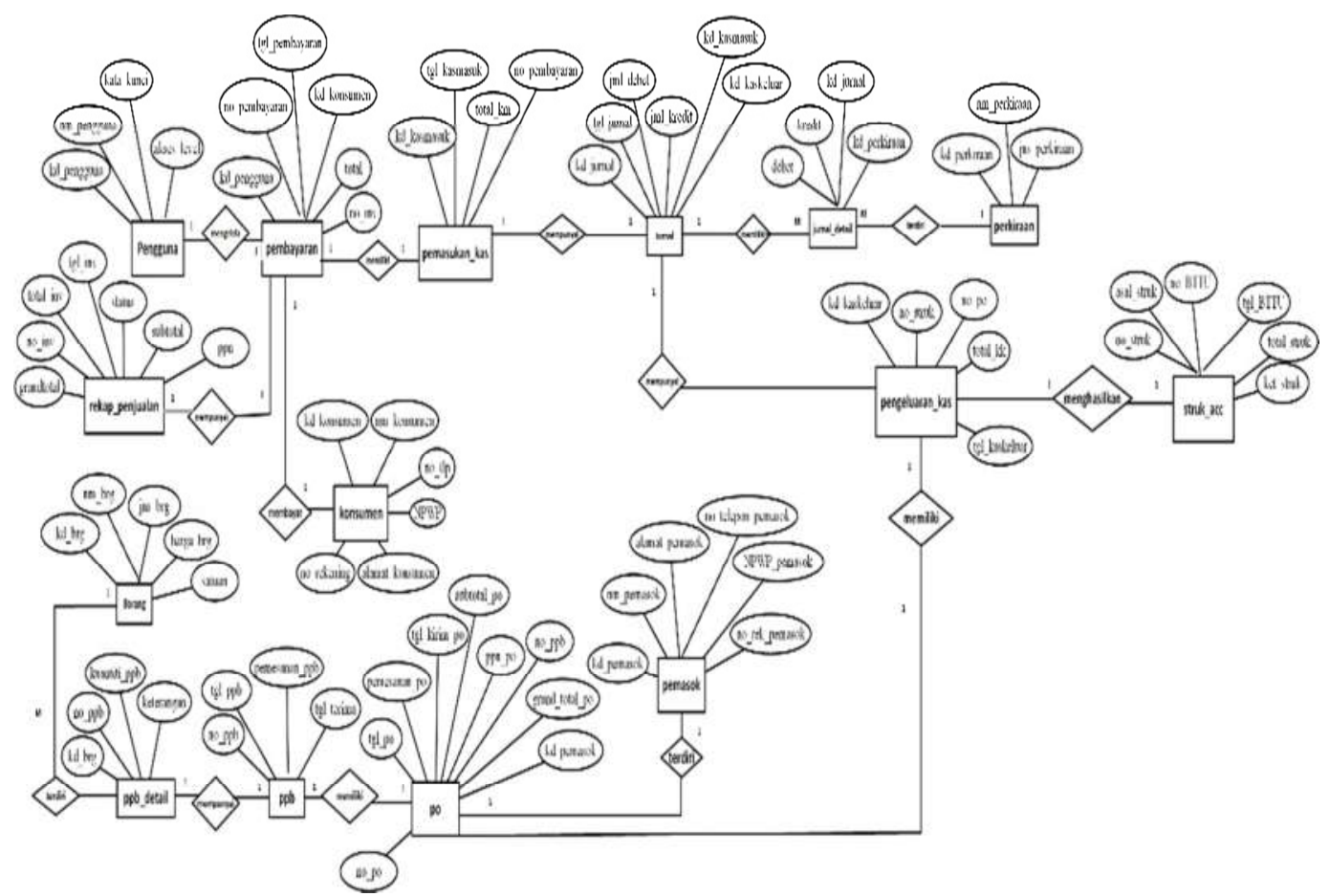

Gambar 3. Diagram ERD Sistem Akuntansi Usulan

\subsection{Logical Relational Structure}

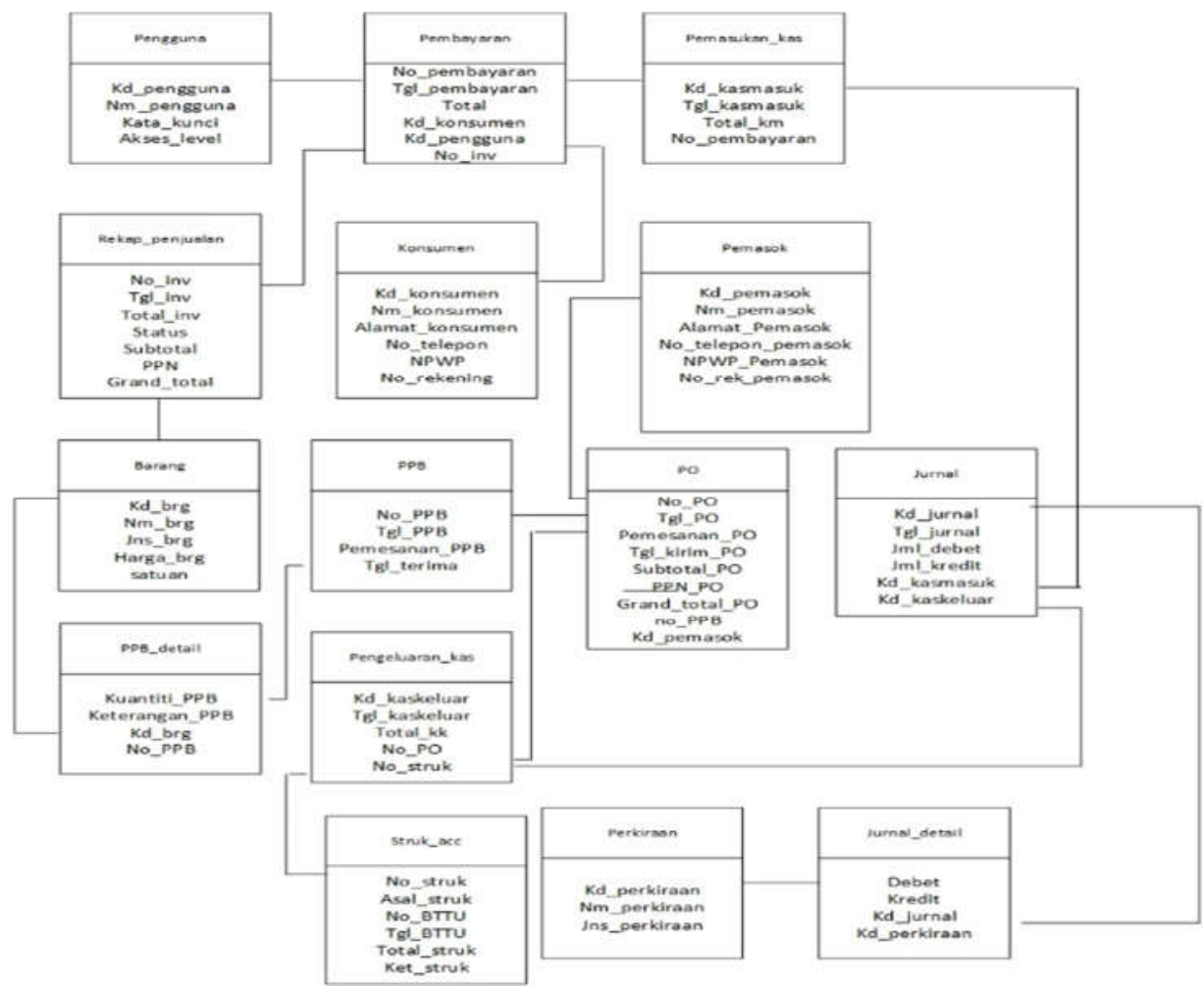

Gambar 4. DiagramERD Sistem Akuntansi Usulan 
Jurnal Inkofar * Volume 1 No. 2, Desember 2018 * ISSN: 2615-3645 (Print) / 2581-2920 (Online) Tersedia secara online di: http://www.politeknikmeta.ac.id/meta/ojs/

\subsection{Implementasi Program}

4.7.1. Tampilan Program Menu Utama

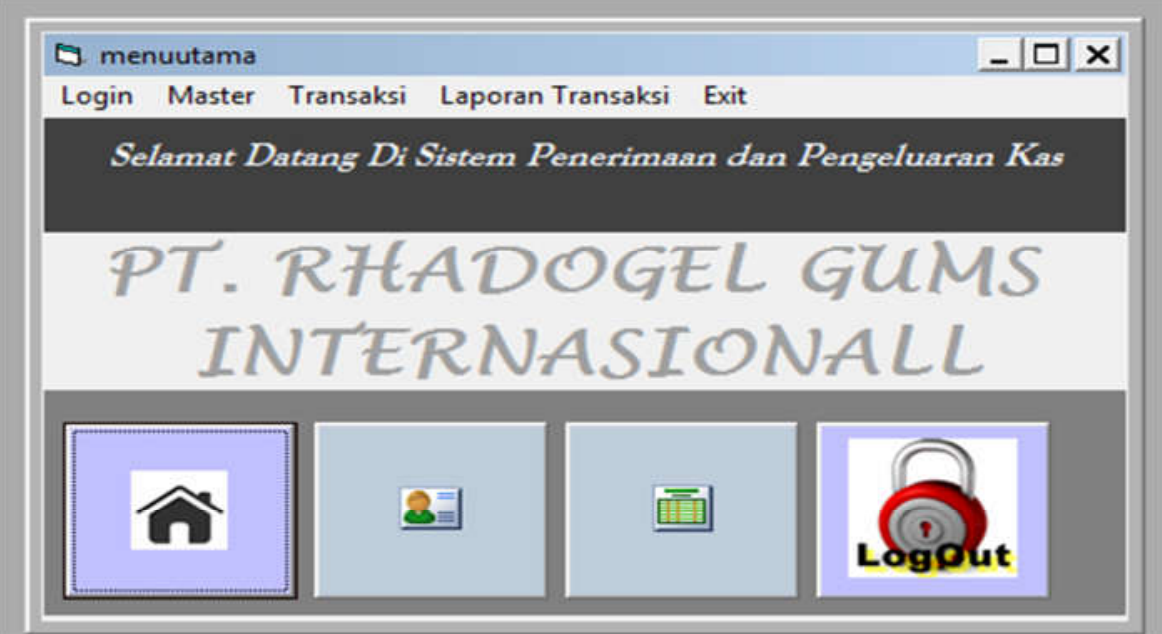

Gambar 5. Tampilan Program Menu Utama Sistem Akuntansi Usulan

4.7.2. Tampilan Program Menu Purchase Order

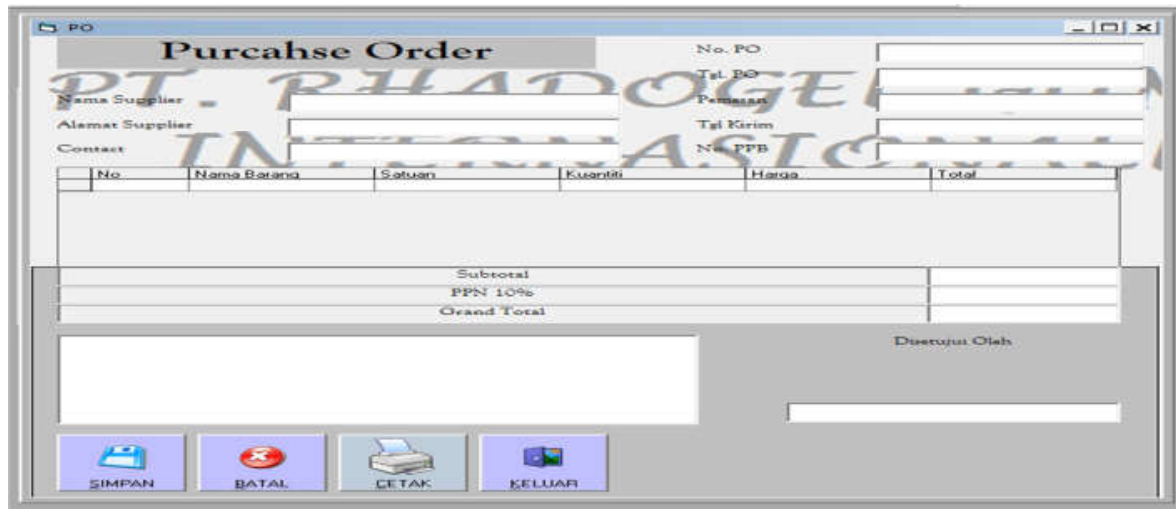

Gambar 6. Tampilan Program Menu Purchase Order Sistem Akuntansi Usulan

\subsubsection{Tampilan Program Menu Kas Keluar}

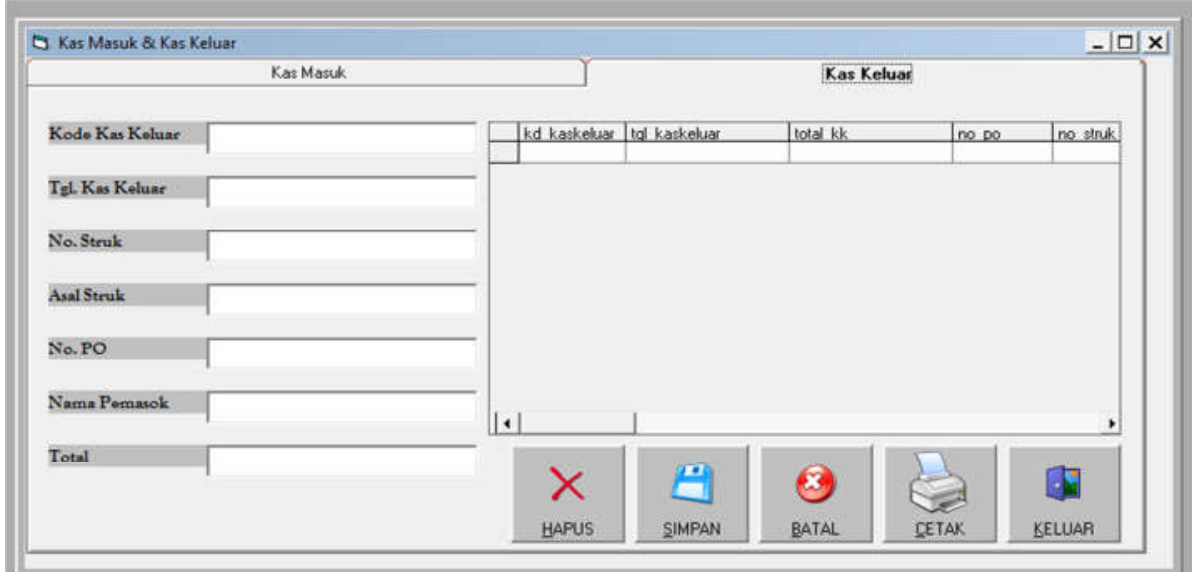

Gambar 7. Tampilan Program Menu Pembayaran Sistem Akuntansi Usulan 
Jurnal Inkofar * Volume 1 No. 2, Desember 2018 * ISSN: 2615-3645 (Print) / 2581-2920 (Online)

Tersedia secara online di: http://www.politeknikmeta.ac.id/meta/ojs/

\subsection{Pengujian Unit}

Tabel 1. Pengujian Black Box Testing Purchase Order

\begin{tabular}{|c|c|c|c|c|c|}
\hline No & $\begin{array}{c}\text { Skenario } \\
\text { Pengujian }\end{array}$ & Test Case & $\begin{array}{c}\text { Hasil yang } \\
\text { diharapkan }\end{array}$ & $\begin{array}{c}\text { Hasil } \\
\text { Pengujian }\end{array}$ & Kesimpulan \\
\hline 1 & $\begin{array}{l}\text { Klik tombol } \\
\text { SIMPAN } \\
\text { ketika sedang } \\
\text { mengisi data di } \\
\text { textfield }\end{array}$ & $\begin{array}{l}\text { No PO : secara otomatis } \\
\text { akan terisi } \\
\text { Tgl PO : secara otomatis } \\
\text { akan terisi } \\
\text { Pemesan, tgl kirim, No. } \\
\text { PPB, Nama supplier, } \\
\text { alamat supplier, contact } \\
\text { tidak di isi. }\end{array}$ & $\begin{array}{l}\text { Sistem akan } \\
\text { menolak }\end{array}$ & $\begin{array}{l}\text { Sesuai } \\
\text { Harapan }\end{array}$ & Valid \\
\hline 2 & $\begin{array}{l}\text { Klik tombol } \\
\text { SIMPAN } \\
\text { ketika sedang } \\
\text { mengisi data di } \\
\text { textfield }\end{array}$ & $\begin{array}{l}\text { No PO : secara otomatis } \\
\text { akan terisi } \\
\text { Tgl PO : secara otomatis } \\
\text { akan terisi } \\
\text { Pemesan, tgl kirim, No. } \\
\text { PPB di isi, Grid otomatis } \\
\text { terisi ketika No PPB di } \\
\text { isi dan di enter } \\
\text { tapi Nama supplier, } \\
\text { alamat supplier, contact } \\
\text { tidak di isi. }\end{array}$ & $\begin{array}{l}\text { Sistem akan } \\
\text { menolak }\end{array}$ & $\begin{array}{l}\text { Sesuai } \\
\text { Harapan }\end{array}$ & Valid \\
\hline 3 & $\begin{array}{l}\text { Klik tombol } \\
\text { BATAL }\end{array}$ & $\begin{array}{l}\text { No PO : secara otomatis } \\
\text { akan terisi } \\
\text { Tgl PO : secara otomatis } \\
\text { akan terisi } \\
\text { Pemesan, tgl kirim, No. } \\
\text { PPB, Nama supplier, } \\
\text { alamat supplier, contact } \\
\text { tidak di isi }\end{array}$ & $\begin{array}{l}\text { Tombol } \\
\text { batal tidak } \\
\text { akan } \\
\text { berfungsi } \\
\text { jika data pad } \\
\text { textfield } \\
\text { Pemesan, tgl } \\
\text { kirim, No. } \\
\text { PPB, Nama } \\
\text { supplier, } \\
\text { alamat } \\
\text { supplier, } \\
\text { contact tidak } \\
\text { di isi }\end{array}$ & $\begin{array}{l}\text { Sesuai } \\
\text { Harapan }\end{array}$ & Valid \\
\hline 4 & $\begin{array}{l}\text { Klik tombol } \\
\text { KELUAR }\end{array}$ & $\begin{array}{l}\text { No PO : secara otomatis } \\
\text { akan terisi } \\
\text { Tgl PO : secara otomatis } \\
\text { akan terisi } \\
\text { Pemesan, tgl kirim, } \\
\text { Nama supplier, alamat } \\
\text { supplier, contact di isi } \\
\text { tapi no ppb dan grid } \\
\text { tidak terisi }\end{array}$ & $\begin{array}{l}\text { Jika di klik } \\
\text { tombol } \\
\text { KELUAR } \\
\text { akan } \\
\text { tampil } \\
\text { jendela } \\
\text { informasi } \\
\text { "Yakin ingin } \\
\text { keluar } \\
\text { tanpa } \\
\text { disimpan?" }\end{array}$ & $\begin{array}{l}\text { Sesuai } \\
\text { Harapan }\end{array}$ & Valid \\
\hline
\end{tabular}




\begin{tabular}{|c|c|c|c|c|c|}
\hline 5 & $\begin{array}{l}\text { Klik tombol } \\
\text { CETAK }\end{array}$ & $\begin{array}{l}\text { No PO : secara otomatis } \\
\text { akan terisi } \\
\text { Tgl PO : secara otomatis } \\
\text { akan terisi } \\
\text { Pemesan, tgl kirim, No. } \\
\text { PPB, Nama supplier, } \\
\text { alamat supplier, contact } \\
\text { tidak di isi }\end{array}$ & $\begin{array}{l}\text { Tombol } \\
\text { batal tidak } \\
\text { akan } \\
\text { berfungsi } \\
\text { jika data pad } \\
\text { textfield } \\
\text { Pemesan, tgl } \\
\text { kirim, No. } \\
\text { PPB, Nama } \\
\text { supplier, } \\
\text { alamat } \\
\text { supplier, } \\
\text { contact tidak } \\
\text { di isi }\end{array}$ & $\begin{array}{l}\text { Sesuai } \\
\text { Harapan }\end{array}$ & Valid \\
\hline
\end{tabular}

\section{KESIMPULAN}

Berdasarkan pembahasan sebelumnya mengenai Perancangan Sistem Informasi Penerimaan dan Pengeluaran Kas pada PT. Rhadogel Gums Internasional,jelas sekali bahwa penerapan sistem yang baru akan sangat membantu dalam pelaksanaan pengelolaan penerimaan dan pengeluaran kas yang terjadi, dengan menggunakan sarana sistem yang terkomputerisasi, sistem informasi pengolahan data penerimaan dan pengeluaran kas ini dapat berjalan dengan mudah juga dapat mempercepat dalam proses pencatatan data transaksinya baik penerimaan maupun pengeluaran kas, serta data data pendukung yang lainnya sehingga lebih efektif dan efisien dalam proses pengolahan datanya sehingga dalam pelaporan pun lebih akurat, efektif juga efisien, selain itu dari segi penyimpanan data dan untuk mencari data akan lebih mudah karena sudah tersimpan dengan rapih dalam bentuk file dibandingkan dengan sistem terdahulu yang bentuk penyimpanannya yang menggunakan dokumen fisik atau masih berupa arsip.

\section{DAFTAR PUSTAKA}

Baridwan, Zaki. 2010. Sistem Informasi Akuntansi. Yogyakarta: BFPE.

Gamaliel, F., 2017. Rancang Bangun Sistem Informasi Akademik Politeknik Meta Industri. Jurnal Inkofar, 1(2).

Herry. 2012. Pengantar Akuntansi 1. Jakarta: LPFE.

Muharam, Agus, Dewi Yuliandari dan Gustap Dimas Sutanto. 2018. Perancangan Sistem Pembelian Material Berorientasi Objek Pada PT. HI-Tech Ink Indonesia Cikarang. Jurnal Infokar, 1(1).

Kendall, Kenneth, E., dan Julie E. Kendall. 2011. Systems Analysis and Designs. New jersey: Pearson Edication.

Kuryanti, Sandra J. 2016. Rancang Bangun Sistem E-Learning Sebagai Sarana Pembelajaran. Jurnal Khatulistiwa Informatika, Vol. 4, No. 1 Juni 2016. Hal 84-92.

Nugraha, Aditya. dan Anita Octasia. 2016. Sistem Informasi Penjualan Kaos Berbasis Web Pada Distro Sickness Berbasis E-Commerce. Jurnal: SNIPTEK. ISBN: 978-60272850-3-3. Hal 299-302.

Puspitawati, Lilis dan Sri Dewi Anggadini, 2011. Sistem Informasi Akuntansi. Yogyakarta: Graha Ilmu.

Sholikhah, Imroatus, Mahmud Sairan dan Nurfia Oktaviani Syamsiah. 2017. Aplikasi Pembelian dan Penjualan Barang Dagang pada CV Gemilang Muliatama Cikarang. Jurnal Teknik Komputer AMIK BSI. Vol. III, No.1, Februari 2017. ISSN. 24422436. 
Jurnal Inkofar * Volume 1 No. 2, Desember 2018 * ISSN: 2615-3645 (Print) / 2581-2920 (Online)

Tersedia secara online di: http://www.politeknikmeta.ac.id/meta/ojs/

Sukamto, Rosa A. dan M. Salahuddin. 2013. Rekayasa Perangkat Lunak Terstruktur dan Berorientasi Objek. Bandung: Informatika.

Sutabri, Tata. 2012. Analisis Sistem Informasi. Jakarta: Andi Offset.

https://republika.co.id/berita/ekonomi/korporasi/18/02/12/p40ezo383-pertumbuhan-

manufaktur-indonesia-tertinggi-di-asean

https://finance.detik.com/industri/d-3929902/sektor-manufaktur-masih-jadi-andalan-genjotpertumbuhan-ekonomi-ri 